\title{
Implementasi Manajemen Berbasis Sekolah Terhadap Kepemimpinan Kepala Sekolah Di MAN 1 Aceh Besar Kabupaten Aceh Besar
}

\author{
Darmawati \\ Fakultas Keguruan dan Ilmu Pendidikan Universitas Serambi Mekkah \\ Email. darmawati@serambimekkah.ac.id
}

\begin{abstract}
Abstrak
Penelitian ini berjudul Implementasi Manajemen Berbasis Sekolah Terhadap Kepemimpinan Kepala Sekolah Di MAN 1 Aceh Besar Kabupaten Aceh Besar". Penelitian ini bertujuan untuk mengetahui Implementasi Manajemen Berbasis Sekolah Terhadap Kepemimpinan Kepala Sekolah Di MAN 1 Aceh Besar Kabupaten Aceh Besar. Penelitian ini dilakukan di MAN 1 Aceh Besar Kabupaten Aceh Besar. Penelitian ini dilaksanakan selama 3 bulan, dimulai pada bulan September 2021 sampai Desember 2021. Penelitian ini menggunakan pendekatan kualitatif dalam bentuk metode deskriptif. Teknik yang digunakan dalam penelitian ini yaitu teknik observasi, wawancara, studi dokumentasi, dan instrument. Data dianalisis melalui proses-proses yaitu klasifikasi, kategorisasi, dan interpretasi. Berdasarkan hasil penelitian yang telah dilakukan penulis, maka membuktikan bahwa Implementasi Manajemen Berbasis Sekolah Terhadap Kepemimpinan Kepala Sekolah Di MAN 1 Aceh Besar Kabupaten Aceh Besar berjalan sangat baik, itu terlihat dari kepemimpinan kepala sekolah, budaya organisasi yang memadai, dan implementasi MBS yang baik, maka guru tersebut akan lebih professional dalam melakukan kegiatan belajar mengajar disekolah.
\end{abstract}

\section{Kata Kunci : Implementasi, Manajemen Berbasis Sekolah, Kepemimpinan Kepala Sekolah}

\section{PENDAHULUAN}

Kepemimpinan kepala sekolah memiliki peran strategi dalam kerangka manajemen dan kepala sekolah merupakan salah satu faktor ter-penting dalam menunjang keberhasilan sekolah dalam mencapai tujuan sekolah yang telah ditetapkan. Kepala sekolah adalah pengelola satuan pendidikan yang bertugas menghimpun, memanfaatkan, mengoptimalkan seluruh potensi dan SDM, sumber daya lingkungan (sarana dan prasarana) serta sumber dana yang ada untuk membina sekolah dan masyarakat sekolah yang dikelolanya (Angraini, 2014).

Pendidikan awalnya memiliki aspek yang amat besar pengaruhnya di dalam diri seseorang. Pendidikan secara umum merupakan suatu hal yang sadar dan terencana dengan baik demi terwujudnya suasana belajar dan proses pembelajaran secara efektif (Nungkiastuti, 2021). Salah satu persoalan pendidikan yang sedang dihadapi bangsa kita adalah persoalan mutu pendidikan. Berbagai usaha telah dilakukan untuk meningkatkan mutu pendidikan nasional, antara lain melalui berbagai pelatihan dan peningkatan kompetensi guru, pengadaan buku dan alat pelajaran, perbaikan sarana dan prasarana pendidikan, dan meningkatkan mutu manajemen sekolah. Namun demikian, indikator mum pendidikan belum menunjukkan peningkatan yang berarti. Sebagian sekolah, terutama di kota-kota, menunjukkan peningkatan mutu pendidikan yang cukup menggembirakan, namun sebagian besar lainnya masih memprihatinkan. 
Seiring waktu, kualitas teknologi terus tumbuh dalam hal kualitas dan kinerja. Peningkatan kualitas adalah suatu keharusan dan harus diterapkan oleh lembaga mana pun. Dalam dunia pendidikan, sangat penting untuk meningkatkan kualitas pendidikan karena kualitasadalah keunggulan produk dibandingkan produk lain (Fadhli, 2017). Kualitas adalah bagian terpenting dari keseluruhan agenda organisasi, dan peningkatan kualitas adalah tugas paling penting yang dihadapi lembaga manapun. Meningkatkan kualitas pendidikan adalah tujuan mengembangkan sektor pendidikan nasional dan bagian penting dari usaha untuk meningkatkan kualitas kemanusiaan (Mulyasa, 2015).

Tentu saja, terkait dengan peningkatan kualitas lembaga pendidikan, tidakmungkin memisahkan lembaga-lembaga ini dari strategi yang direncanakan untuk membangun manajemen untuk meningkatkan kualitas lembaga pendidikan. Kualitas sangat penting dalam proses pendidikan. Dari sudut pandang makroskopis, ada beberapa faktor yang mempengaruhi kualitas pendidikan. Termasuk fasilitas pendidikan yang memiliki faktor kurikulum, kebijakan pendidikan, strategi modern dan diimbangi dengan manajemen profesional (Nurhayati, 2010).

Sallis dalam (Merdekawati, 2011) menjelaskan dalam meningkatkan suatu mutu di dalam lembaga pendidikan maka suatu organisasi harus memiliki 1) nilai moral dalam lembaga pendidikan itu sendiri, dengan pengecualian perspektif makroskopis dalam meningkatkan kualitas pendidikan; 2) hasil tes yang sangat memuaskan; 3) dukungan dari orang tua, komunitas bisnis dan komunitas sekitarnya; 4) sumber daya yang melimpah; 5)Implementasi teknologi terbaru; 6) kepemimpinan dan tujuan (visi) yang kuat; 7) minat dan minat pada siswa; 8) Kurikulum Terkait yang Seimbang.

Manajemen Berbasis Sekolah (MBS) adalah sejenis manajemen sekolah yang mempromosikan pemberdayaan kelompok yang lebih besar dan mendorong pengambilan keputusan bersama di semua penghuni sekolah dan masyarakat sekitar dalam upaya meningkatkan dan meningkatkan kualitas pendidikan (Khairunniswah, 2020).

Menurut (Suhardan, 2010) menjelaskan bahwa Manajemen Berbasis Sekolah adalah desain manajemen yang menyediakan sekolah dengan kebijakan independen yang berkontribusi pada pengambilan keputusan yang melibatkan semua anggota sekolah secara langsung sesuai dengan standar layanan pemerintah pusat, negara bagian dan lokal. Manajemen berbasis sekolah secara garis besar merupakan suatu pedoman dalam memenejemen kegiatanyang telah dirancang oleh sekolah dalam mencapai tujuan yang telah di inginkan. Dalam artian manajemen ini sebenarnya memiliki sistem dimana memberikan otonomi kepada pihak lembaga sekolah untuk mengelola sekolahnya sendiri, tapi dengan acuan yang sudah di rencanakan oleh pemeritah tapi lembaga sekolah-lah yang memiliki otoritas tertinggi dalam mengembangkan dan menentukan kebijakan yang akan diambil dalam melakukan pengembangan peningkatan mutu pendidikan.

UU No.20 tahun 2003 tentang Sistem Pendidikan Nasional dengan pasal 51 yang menyatakan pengelolaan satuan pendidikan anak usia dini, pendidikan dasar, dan pendidikan menengah didasarkan pada standar pelayanan minimum dengan prinsip manajemen berbasis sekolah (UURI, 2003). Kepemimpinan adalah cara seseorang pemimpin mempengaruhi perilaku bawahan agar mau bekerja sama dan bekerja secara produktif untuk mencapai tujuan organisasi. Gaya kepemimpinan yang kurang 
melibatkan bawahan dalam mengambil keputusan maka akan mengakibatkan adanya disharmonisasi hubungan anatara pemimpin dan yang dipimpin.

Kepemimpinan merupakan salah satu faktor yang menentukan kesuksesan implementasi MBS. Sebagaimana dikemukakan oleh Nurkolis setidaknya ada empat alasan kenapa diperlukan figur pemimpin, yaitu ; 1) Banyak orang memerlukan figur pemimpin, 2) Dalam beberapa situasi seorang pemimpin perlu tampil mewakili kelompoknya, 3) Sebagai tempat pengambilalihan resiko bila terjadi tekanan terhadap kelompoknya, dan 4) Sebagai tempat untuk meletakkan kekuasaan (Nurkholis, 2006). Manajemen Berbasis Sekolah memberikan keleluasaan kepada sekolah untuk mengelola potensi yang dimiliki dengan melibatkan semua unsur stake holder untuk mencapai peningkatan kualitas sekolah tersebut. Karena sekolah memiliki kewenangan yang sangat luas itu maka kehadiran figur pemimpin menjadi sangat penting.

Kepemimpinan yang baik tentunya sangat berdampak pada tercapai tidaknya tujuan organisasi karena pemimpin memiliki pengaruh terhadap kinerja yang dipimpinnya. Kemampuan untuk mempengaruhi suatu kelompok untuk mencapai tujuan merupakan bagian dari kepemimpinan (Nurkholis, 2006). Konsep kepemimpinan erat sekali hubungannya dengan konsep kekuasaan. Para pemimpin menggunakan kekuasaan sebagai alat untuk mencapai tujuan kelompok. Pemimpin mempunyai sasaran, dan kekuasaan merupakan sarana untuk memudahkan mencapai sasaran itu (Stephen,2008). Terdapat beberapa sumber dan bentuk kekuasaan, yaitu kekuasaan paksaan, legitimasi, keahlian, penghargaan, referensi, informasi, dan hubungan.

Gaya kepemimpinan adalah sikap, gerak-gerik atau lagak yang dipilih oleh seseorang pemimpin dalam menjalankan tugas kepemimpinannya Gaya yang dipakai oleh seorang pemimpin satu dengan yang lain berlainan tergantung situasi dan kondisi kepemimpinannya Gaya kepemimpinan menjadi norma perilaku yang dipergunakan seseorang pada saat orang tersebut mencoba mempengaruh perilaku orang lain serta sebagai suatu pola perilaku yang konsisten yang ditinjukan oleh pemimpin dan diketahui pihak lain ketika pemimpin berusaha mempengaruhi kegiatan-kegiatan orang lain. Berdasarkan uraian diatas maka penulis tertarik untuk melakukan penelitian "Implementasi Manajemen Berbasis Sekolah Terhadap Kepemimpinan Kepala Sekolah Di MAN 1 Aceh Besar Kabupaten Aceh Besar".

\section{Tujuan Penelitian}

Penelitian ini bertujuan untuk mengetahui Implementasi Manajemen Berbasis Sekolah Terhadap Kepemimpinan Kepala Sekolah Di MAN 1 Aceh Besar Kabupaten Aceh Besar.

\section{Kajian Pustaka}

\section{Manajemen Berbasis Sekolah}

Manajemen berbasis sekolah merupakan pengkoordinasian dan penyerasian sumber daya yang dilakukan secara otonomis oleh sekolah melalui sejumlah input manajemen untuk mencapai tujuan sekolah dalam bingkai pendidikan nasional, dengan melibatkan semua kelompok kepentingan yang terkait dengan sekolah secara langsung dalam proses pengambilan keputusan (partisipatif) (Hamid, 2013).

Tujuan pelaksanaan MBS adalah untuk memberdayakan sekolah, terutama sumber daya manusianya (kepala sekolah, guru, karyawan, siswa, orang tua, dan masyarakat sekitarnya), melalui pemberian kewenangan, fleksibilitas, dan sumber daya lain untuk memecahkan persoalan yang dihadapi oleh sekolah yang bersangkutan. Ciri- 
ciri sekolah yang "berdaya" adalah: 1) Tingkat kemandirian tinggi 2) Tingkat ketergantungan rendah 3) Bersifat adaptif, antisipatif dan proaktif 4) Memiliki jiwa kewirausahaan tinggi 5) Bertanggungjawab terhadap hasil sekolah 6) Memiliki kontrol yang kuat terhadap input manajemen dan sumber dayanya 7) Kontrol terhadap kondisi kerja 8) Komitmen yang tinggi pada dirinya 9) Dinilai oleh pencapaian prestasinya (Hamid, 2013).

\section{Pengertian kepemimpinan}

Pemimpin memiliki peranan yang dominan dalam sebuah organisasi. Peranan yang dominan tersebut dapat mempengaruhi moral kepuasan kerja, keamanan, kualitas kehidupan kerja dan terutama tingkat prestasi suatu organisasi. Sebagaimana dikatakan Hani Handoko, bahwa pemimpin juga memainkan peranan kritis dalam membantu kelompok organisasi, atau masyarakat untuk mencapai tujuan mereka (Handoko, 1995).

Bagaimanapun juga kemampuan dan keterampilan kepemimpinan dalam pengarahan adalah faktor penting efektifitas manajer. Bila organisasi dapat mengidentifikasikan kualitas yang berhubungan dengan kepemimpinan kemampuan mengidentifikasikan perilaku dan teknik-teknik kepemimpinan efektif. Kepemimpinan dalam bahasa inggris tersebut leadership berarti being a leader, power of leading atau the qualities of leader (Hornby, 1990).

\section{Gaya Kepemimpinan}

Gaya adalah sikap, gerak-gerik atau lagak yang menandai ciri seseorang. Berdasarkan pengertian tersebut maka gaya kepemimpinan adalah sikap, gerakgerik atau lagak yang dipilih oleh seorang pemimpin dalam menjalankan tugas kepemimpinannya Gaya yang dipakai oleh seseorang pemimpin satu dengan yang lain berlainan tergantung situasi dan kondisi kepemimpinannya

Menurut pendekatan tingkah laku, gaya kepemimpinan adalah pola menyeluruh dari tindakan seorang pemimpin, baik yang tampak maupun yang tidak tampak oleh bawahannya. Gaya kepemimpinan menggambarkan kombinasi yang konsisten dari falsafah, keterampilan, sifat dan sikap yang mendasari perilaku seseorang.

Gaya kepemimpinan yang berkaitan dengan MBS berkaitan dengan proses mempengaruhi antara para pemimpin dengan para pengikutnya. Dalam kepemimpinan partisipatif, menyangkut usaha-usaha oleh seorang pemimpin untuk mendorong dan memudahkan partisipasi orang lain dalam pengambilan keputusan. Dalam kepemimpinan partisipatif juga digunakan pendekatan kekuasaan, yaitu secara bersama-sama membagi kekuasaan (power sharing) dan proses-proses mempengaruhi timbal balik, pendelegasian kekuasaaan, dan konsultasi dengan orang lain untuk memperoleh saran-saran.

\section{METODE PENELITIAN}

\section{Tempat dan Waktu Penelitian}

Penelitian ini dilakukan di MAN 1 Aceh Besar Kabupaten Aceh Besar. Penelitian ini dilaksanakan selama 3 bulan, dimulai pada bulan September 2021 sampai Desember 2021. Penelitian ini menggunakan pendekatan kualitatif dalam bentuk metode deskriptif. 


\section{Tehnik Pengumpulan Data}

Teknik yang digunakan dalam penelitian ini yaitu teknik observasi, wawancara, studi dokumentasi, dan instrument.

\section{Tehnik Analisis Data} interpretasi.

Data dianalisis melalui proses-proses yaitu klasifikasi, kategorisasi, dan

\section{HASIL PENELITIAN DAN PEMBAHASAN Deskripsi Data}

Dari wawancara dengan responden yang dilengkapi dengan basil observasi dan studi dokumentasi maka diperoleh hasil penelitian sebagai berikut :

\section{Visi dan Misi MAN 1 ACEH BESAR :}

Dari hasil studi dokumen, didapatkan bahwa visi MAN 1 Aceh Besar adalah Mewujudkan Siswa Yang Santun, Terampil, Mandiri Berwawasan Imtaq Dan Iptek. Misi MAN 1 Aceh Besar adalah :

$>$ Meningkatkan Kemampuan Pendidik yang Profesional sesuai dengan kompetensinya dalam kegiatan Belajar Mengajar.

$>$ Melaksanakan Bimbingan Keagamaan yang Kreatif dan Inovatif.

$>$ Meningkatkan Kualitas Keilmuan Siswa melalui Uji Kompetensi.

> MelaksanakanKegiatan Proses Belajar Mengajar yang Efektif dan Efisien.

$>$ Meningkatrkan Keterampilan dan Kemandirian Sesuai dengan Bakat Minat Siswa Melalui Kegiatan Ekstrakurikuler.

Berdasarkan latar belakangnya, MBS di MAN 1 Aceh Besar muncul karena fakta menunjukan bahwa kualitas pendidikan di Indonesia masih rendah. Adanya desakan dan kritikan dari masyarakat luas memaksa pemegang otoritas pendidikan untuk mereformasi sekolah mereka sendiri, sehingga visi misi sekolah dibuat dan disusun agar sesuai dengan kebutuhan dan tuntutan masyarakat agar kelak alumni MAN 1 Aceh Besar memiliki pengetahuan dan keterampilan, kapasitas pribadi yang mumpuni, memiliki kemampuan nalar tinggi, mampu berfikir ilmiah, memiliki kepekaan sosial tinggi dan mandiri.

\section{Adapun proses penetapan visi dan misi di MAN 1 Aceh Besar adalah :}

Proses penetapan diawali dengan rapat pimpinan MAN 1 Aceh Besar yang terdiri dari Kepala Sekolah, wakil Kepala Sekolah bagian kurikulum dan wakil kepala sekolah bagian kesiswaan serta Ketua Komite Sekolah. Visi MAN 1 Aceh Besar (Mewujudkan Siswa Yang Santun, Terampil, Mandiri Berwawasan Imtaq Dan Iptek).

Dari sinilah kemudian dikembangkan pembicaraan visi MAN 1 Aceh Besar, dalam pembicaraan rapat diharapkan muncul gagasan visi yang bersifat fleksibel dan dinamis, sehingga dapat berlaku dalam waktu yang panjang dengan fleksibilitasnya dan dengan visi tersebut tetap dapat dilakukan pengembangan misi dan orientasi yang dinamis.

\section{Upaya yang dilakukan MAN 1 Aceh Besar untuk mencapai visi dan misi tersebut :}

Upaya-upaya yang telah dilakukan MAN 1 Aceh Besar dalam mencapai Visi-Misinya: 
a. Penyusunan Rencana Strategi sekolah dalam bentuk Program Kerja Jangka Panjang, jangka menengah dan jangka pendek (tahunan)

b. Menyelenggarakan pembinaan akhlaq dan nilai-nilai keagamaan melalui program terjadwal (sebagai kegiatan awal pembelajaran)

c. Menginstruksikan agar dilakukan pengintegrasian nilai-nilai agama dan moral (budi pekerti) dalam setiap pembelajaran

d. Menyelenggarakan Program Pengayaan dan Bimbingan Belajar

e. Mengaktifkan program Ekstra kurikuler dalam bidang keilmuan

f. Pembekalan Keterampilan keagamaan (Baca Al-Qur'an, Penyelenggaraan sholat-sholat sunnat, Mengurus Mayit) melalui program PAI Mulok

g. Melaksanakan Pembinaan dan pengembangan kemampuan berbahasa Inggris bagi dewan guru melalui program English for Teacher

h. Melaksanakan pembinaan penguasaan pemanfaatan teknologi komputer bagi guru (pembinaan penggunaan komputer sebagai alat bantu/media pembelajaran)

i. Melaksanakan pembinaan kompetensi guru

j. Melaksanakan dan melanjutkan proses pengadaan sarana prasarana penunjang pelaksanaan pendidikan (renovasi laboratorium dan pengadaan alat dan bahan praktek, pengadaan LCD untuk pembelajaran, Pengadaan jaringan Internet, Penyiapan Pengadaan Pusat Sumber Belajar berbasis ICT, d11)

\section{Keterlibatan guru dan karyawan dalam penyusunan visi dan misi :}

Semua guru dan karyawan diberikan keleluasaan dalam memberikan kontribusi berupa masukan, saran, ide, dan perbaikan. Rapat perumusan visi yang dilaksanakan sebelumnya oleh pihak yayasan dengan pimpinan sekolah, menetapkan pula bahwa unit pendidikan (MAN 1 Aceh Besar) diharapkan dalam satu minggu setelah rapat telah dapat menyusun misi unit pendidikannya untuk menjadi bahan acuan dalam rapat dewan guru dan komite sekolah.

Konsep dasar misi dan tujuan sekolah yang disusun oleh kepala sekolah dan pimpinan lainnya diajukan, dibahas, kemudian disepakati. Draft tersebut disepakati dalam rapat/workshop guru dan karyawan yang dilakukan setiap awal semester. Sosialisasi visi dan misi dilakukan dengan menempelkan di setiap tempat yang mudah terbaca oleh warga sekolah, baik di kantor, ruang guru, ruang tata usaha, dan ruang kelas. Bagi guru/karyawan ban', sosialisasi visi dan misi diberikan dalam diklat guru/karyawan baru, sedangkan bagi siswa baru dilakukan dalam Masa Orientasi Peserta Didik (MOPD) pada awal tahun pelajaran.

\section{Manfaat keterlibatan pengelola dalam penyusunan visi dan misi tersebut:}

Dengan dilibatkan segenap pengelola baik guru maupun karyawan, maka akan berakibat:

a. Pengelola merasa dihargai yang berdampak pada peningkatan kinerja dan munculnya kreatifitas.

b. Pengelola merasa bertanggung jawab atas kelancaran dan kemajuan sekolah. Pengelola berusaha merealisasikan visi dan misi tersebut sesuai dengan kemampuan dan ruang lingkup kerjanya.

c. Timbul rasa memiliki yang berdampak pada loyalitas dan dedikasi.

d. Keterlibatan seluruh komoditas sekolah ini, akan membawa warga sekolah dihargai dalam pengambilan keputusan sekolah, sehingga menciptakan transparansi dan demokrasi yang sehat. 


\section{Dampak Manajemen Berbasis Sekolah (MBS) di sekolah dalam menentukan berbagai kebijakan.}

Sejalan dengan pemberlakuan undang-undang otonomi daerah, maka Depdiknas telah melakukan penyesuaian-penyesuaian terhadap pendekatan manajemen pendidikan yaitu dari manajemen berbasis pusat menuju manajemen berbasis sekolah, seperti yang tercantum pada tabel berikut:

\begin{tabular}{|c|c|c|}
\hline $\begin{array}{c}\text { Manajemen Berbasis } \\
\text { Pusat }\end{array}$ & Menuju & $\begin{array}{c}\text { Manajemen Berbasis } \\
\text { Sekolah }\end{array}$ \\
\hline Sub-ordinasi & & Otonomi \\
\hline Pengambilan keputusan & & Pengambilan keputusan \\
\hline Terpusat & & Partisipatif \\
\hline Ruang gerak kaku & & Ruang gerak luwes \\
\hline Pendekatan birokratik & & Pendekatan profesionalisme \\
\hline Sentralistik & & Desentralistik \\
\hline Diatur & & Motivasi diri \\
\hline Overregulasi & & Deregulasi \\
\hline Mengontrol & & Mempengaruhi \\
\hline Mengarahkan & & engarahkan Memfasilitasi \\
\hline Menghindari resiko & & $\begin{array}{l}\text { Menghindari resiko } \\
\text { Mengolah resiko }\end{array}$ \\
\hline Gunakan uang semuanya & & $\begin{array}{l}\text { Gunakan uang seefisien } \\
\text { mungkin }\end{array}$ \\
\hline Individual cerdas & & $\begin{array}{l}\text { Teamwork kompak \& } \\
\text { cerdas }\end{array}$ \\
\hline Informasi terpribadi & & Informasi terbagi \\
\hline
\end{tabular}

Sumber : Slamet PH, 2000

Karakteristik Manajemen Berbasis Sekolah (MBS) Manajemen berbasis sekolah memiliki karakteristik yang perlu dipahami oleh sekolah yang akan menerapkannya. Dengan kata lain, jika sekolah ingin berhasil dalam menerapkan MBS, maka beberapa karakteristik MBS perlu dipelajari dan dipahami dengan baik. Membahas karakteristik MBS tidak dapat dipisahkan dengan karakteristik sekolah efektif. Jika MBS dianggap sebagai wadah/kerangkanya maka sekolah efektif merupakan isinya. Oleh sebab itu, karkteristik MBS memuat elemen-elemen sekolah efektif yang dikategorikan menjadi input, proses dan output.

Pelaksanaan manajemen berbasis sekolah sangat bagus di MAN 1 Aceh Besar. Sebagai sekolah Negeri yang dana operasionalnya tergantung pada subsidi pemerintah, maka sekolah lebih bersifat terbuka/umum dalam pengelolaannya. Dalam pendekatan ini, tanggung jawab pengambilan keputusan tertentu mengenai anggaran, kepegawaian dan kurikulum ditempatkan di tingkat sekolah. Pergeseran tanggung jawab ini diharapkan dapat menciptakan lingkungan bekerja bagi guru dan karyawan lebih kondusif, lingkungan belajar yang lebih efektif bagi siswa. Dengan demikian MBS adalah upaya memandirikan sekolah dengan memberdayakannya.

Otonomi sekolah di MAN 1 Aceh Besar ini nampak dalam hal :

\section{a. Pengangkatan Kepala Sekolah}

Hal ini menjadi hak prerogatif dinas pendidikan, akan tetapi tetap mempertimbangkan aspek profesionalisme dan kompetensi. Dinas pendidikan kemudian menetapkan kepala sekolah. Ruang lingkup kerja kepala sekolah diserahkan kepada kepala sekolah untuk mengaturnya. Dinas hanya memberikan arahan agar 
sekolah tetap bisa bertahan dan memiliki daya saing. Tataran teknis diserahkan kepada kepala sekolah

Perencanaan Program Sekolah

\section{b. Sebagai pemegang amanah}

Kepala sekolah tidak mengambil keputusan sendiri. Segala bentuk perencanaan dimatangkan di tingkat pimpinan sekolah. Setelah disepakati di tingkat pimpinan, barn dibicarakan dalam konteks luas dengan melibatkan guru atau karyawan. Sehingga semua dilibatkan dalam proses perencanaan. Memang hal ini akan alot dan memakan waktu lama, namun semua dapat beradaptasi dalam berbagai keputusan sekolah.

\section{c. Penyusunan RAPBS}

RAPBS mengacu pada evaluasi laporan akhir tahun lalu, dan prediksi pengeluaran tahun yang akan datang Pimpinan yayasan menganalisa dana yang terserap dan berbagai pengeluaran sesuai bidangnya yang belum teranggarkan. Diharapkan perencanaan tahun yang akan datang dapat lebih matang berdasarkan pengalaman tahun sebelumnya. Perencanaan anggaran ini disesuaikan dengan kebutuhan pimpinan sekolah.

Program yang sudah direncanakan dalam rencana operasional sekolah dan dianggarkan dalam RAPBS kemudian didistribusikan kepada para penanggung jawab kegiatan, yaitu wakil kepala sekolah dan kepala tata usaha. Namun apabila ada kegiatan yang berbarengan, maka disepakati guru lain terlibat dalam kepanitiaan. Hal ini menjadi proses kaderisasi agar ke depan bila terjadi rotasi kepemimpinan sudah terbaca siapa kader yang bisa memimpin8. Kepala sekolah lebih bersifat memberikan arahan dan memonitor kegiatan. Sehingga pelaksana lebih leluasa untuk berinovasi dalam melaksanakan program.

\section{d. Supervisi dan Evaluasi}

Merupakan kegiatan yang menjadi agenda rutin sekolah, baik kepada guru maupun karyawan. Dilakukan jadwal dna tindak lanjut yang jelas9. Hasilnya ditindaklanjuti oleh kepala sekolah secara formal, yaitu guru atau karyawan akan diminta menghadap kepala sekolah maupun informal dengan kepala sekolah langsung berbincang mengenai kesulitan yang dihadapi di lapangan. Selanjutnya kepala sekolah memberikan arahan bagaimana sebaiknya. Setelah setiap personal mengetahui tugas dan fungsinya sebagai guru atau karyawan, kepala sekolah akan mensupervisi dengan mengingatkan kembali berbagai hal yang berkaitan dengan tugas dan fungsi guru atau karyawan tersebut.

Kegiatan informal terasa lebih dominan dilakukan karena lebih bersifat kekeluargaan dan dapat dilakukan lebih aktual dengan memanfaatkan kesempatan dimana guru memang selalu ada di lingkungan sekolah. Guru atau karyawan lebih terbuka dan tanpa tekanan untuk mengungkapkan ide, gagasan, bahkan permohonan maaf bila ada kekeliruan dalam bekerja. Dan semuanya dapat dilakukan dengan kekeluargaan.

Iklim seperti ini tidak berarti melemahkan sikap tegas kepala sekolah. Baik formal maupun informal, harus dibiasakan sebagai bentuk perhatian. Ini terjadi antar kepala sekolah kepada guru atau karyawan atau sebaliknya. Bahkan diantara sesama guru atau karyawan terbangun semangat kebersamaan untuk saling mengingagtkan.

Setiap sekali dalam semester guru akan diseupervisi baik oleh guru senior yang ditunjuk, biasanya wakil kepala sekolah, maupun langsung oleh kepala sekolah. Namun tetap mengkomunikasikan kepada guru yang bersangkutan dilakukan oleh kepala sekolah sebagai bagian dari pembinaan Masalah yang dominan, kemudian dianalisa dan dijadikan bahan evaluasi. 


\section{Kesimpulan}

Berdasarkan hasil penelitian yang telah dilakukan penulis, maka membuktikan bahwa Implementasi Manajemen Berbasis Sekolah Terhadap Kepemimpinan Kepala Sekolah Di MAN 1 Aceh Besar Kabupaten Aceh Besar berjalan sangat baik, itu terlihat dari kepemimpinan kepala sekolah, budaya organisasi yang memadai, dan implementasi MBS yang baik, maka guru tersebut akan lebih professional dalam melakukan kegiatan belajar mengajar disekolah, sehingga peserta didik menerima pelajaran dengan senang hati.

\section{DAFTAR PUSTAKA}

AS. Hornby. Oxford Edvanced Dictionary of English. (London : Oxford University Press, 1990

Depdiknas, Manajemen Berbasis Sekolah. (Jakarta : Program Guru Bantu - Direktorat Tenaga Kependidikan, 2003) h.4

Dewi Nirmala Anggarini. 2014. Kontribusi Kepemimpinan Kepala Sekolah, Budaya Organisasi Dan Implementasi Manajemen Berbasis Sekolah Terhadap Mutu SMP Negeri Di Kabupaten Pemalang. Educational Management 3 (1). ISSN 2252-7001. Universitas Negeri Semarang

Fauzia Damas Nungkiastuti, Amie Kusumawardhani. 2021. Implementasi Manajemen Berbasis Sekolah Tingkat SMA Dalam Pengelolaan Manajemen Mutu-ISO 9001:2008

Hari Handoko, Manajemen edisi kedua, (Yogyakarta : BPFE, 1995) h.293

Hamid. 2013. Manajemen Berbasis Sekolah. Al-Khwarizmi, Vol.I, Maret 2013.

Mulyasa. 2015. Menjadi Guru Profersional Menciptakan Pembelajaran Kreatif Dan. Menyenangkan. Bandung: PT Remaja Rosdakarya

Merdekawati, D. P., \& Sulistyawati, A. I. 2012. Faktor-Faktor yang Mempengaruhi Pemilihan Karier Akuntan Publik dan Non Akuntan Publik. Jurnal Ilmu Ekonomi ASET, 13.

Nurkolis. Manajemen Berbasis Sekolah (Jakarta : PT.Grasindo, 2006) Cet.III, h.152

Nurhayati, 2010. Psikologi dalam pendidikan. Alfabeta. Bandung.

Dadang Suhardan, 2010. Supervisi Profesional Layanan Dalam Meningkatakan Mutu Pembelajaran Diera Otonomi Daerah, Bandung: Alfabeta.

Stephen P. Robbins, Perilaku Organisasi Edisi Kesepuluh, (Jakarta : PT. Indeks, 2008) h. 505

Undang-Undang RI No. 20 Tahun 2003, Sistem Pendidikan Nasional (Jakarta : Fokus Media, 2006) h.83 